\title{
(What about) the Further Enlargement of the EU? In between European Enlargement Fatigue and Balkan I nstability Challenges
}

\author{
Milenko Petrovic \\ National Centre for Research on Europe \\ University of Canterbury \\ milenko.petrovic@canterbury.ac.nz
}

\begin{abstract}
Despite an initial delay in post-communist reforms and opening the EU accession process, Bulgaria and Romania have already succeeded in becoming EU members while Croatia is just a 'step away' from full membership status. Although considerably behind these three, the remaining (Western) Balkan states have been progressing fairly well in the association negotiations (i.e. Stabilisation and Association Process) with the European Union since the early 2000s and expect to officially open negotiations for accession (as is the case with FYR Macedonia) or get full candidate status by the end of 2009 or in 2010 at the latest. However, on their way to Europe, these countries have still to overcome some challenges which the previous EU membership candidates from post-communist Europe faced to a significantly lesser extent or not at all. Focusing on the problems of the increased toughness of EU accession criteria due to the declining public support in the 'old' EU member states for further EU enlargement and on the interior political instability in the countries of the Western Balkans, caused primarily by their still 'undefined' statehood status, this paper investigates the character and strength of the remaining obstacles for further enlargement of the European Union into the Balkan region.
\end{abstract}

After the repeatedly expressed strong commitment of top EU and memberstate leaders to the 'EU futures' of the Western Balkan countries and an even more important signing of the Stabilisation and Association Agreements (SAA) with Serbia and with Bosnia and Herzegovina during the first half of 2008, it appeared that a period of rapid acceleration of the EU accession process has arrived for all countries in the region. However, during that same year the 'incomplete' recognition of Kosovo's independence by most members of the EU and the failed Irish referendum on the adoption of the Lisbon Treaty as the de facto new constitutional treaty of the EU also occurred. These developments have respectively put new wind into the sails of the already existing problems of a continuously fragile internal political stability in most countries in the Western Balkans and declining public support for further EU enlargement among the Western members of the Union, which have threatened to further delay the already 'done deal' of incorporation of the Balkan region as a whole into the European Union. Despite the 'yes' vote to the Lisbon Treaty in the repeated Irish referendum of 2 October 2009 and the continuous expression of very strong optimism by political leaders on both sides - the current EU member states and potential candidates - the 
accession of the remaining Balkan states into the European Union might be a tougher and more complicated task that it had seemed at the time when Serbian and Bosnian leaders signed their respective SAAs with EU officials.

This article focuses on the character and strength of the remaining two most serious obstacles to the integration of the Balkans (i.e. Western Balkans) as a whole into the European Union. Particular attention is paid to the EU's role in the creation and/or maintaining of both of these obstacles: the increased toughness of EU accession criteria due to declining public support in the western member states of the European Union for its further enlargement and the prolonged political instability in the Western Balkans due to the unresolved statehood status of most countries in the region. While the role of the EU is obvious with regard to the first of these two obstacles, the importance of the EU in 'maintaining' the prolonged political instability of the Western Balkan states regarding their statehood status has often been overshadowed by domestic factors and is still waiting to receive proper attention in the mainstream literature. ${ }^{1}$ However, the EU's role in the prolonged statehood disputes in the contemporary democratic and 'proEuropean' Western Balkans is worth a deeper investigation for at least two important reasons. The first one is related to the EU's ability to largely force the implementation of a particular statehood solution by the use of its conditionality criteria for association and accession, while the second is rooted in the very origins of the Balkan statehood problems, which have mostly resulted from the inability of disputing national and ethnic groups to find a peaceful solution to their contrasting positions without foreign assistance. Furthermore, some of these states have been functioning more or less as semiprotectorates of the UN and/ or EU for a number of years and the involvement of the latter in finding a solution to the 'final' statehood status of these states is simply unavoidable.

After referring to the rationale for EU enlargement into the Balkan region and providing a brief overview of EU policy incentives towards the late postcommunist developers from this region since the mid 1990s, this article provides a closer look at the causes of the emergence, basic features and main impacts of both of these two obstacles on the Western Balkan states' accession perspectives. The objectives and scopes of recent EU incentives for resolving the statehood status disputes of some Western Balkan states are then examined in the article's final part.

\footnotetext{
${ }^{1}$ Among the rare works which address this issue, albeit rather narrowly and almost exclusively with regards to the cases of the EU's support for the statehood of two Western Balkan confederations: Bosnia-Herzegovina and (at the time of writing) the already three years nonexistent Serbia and Montenegro (see footnote 48) are worth noting: E. T. Fakiolas and N. Tzifakis, 'Transformation or Accession? Reflecting on the EU's Strategy Towards the Western Balkans', European Foreign Affairs Review, Vol. 13, No. 3, 2008, pp. 377-398; N. Tzifakis, 'EU's region-building and boundary-drawing policies: the European approach to the Southern Mediterranean and the Western Balkans', J ournal of Southern Europe and the Balkans, Vol. 9, No. 1, 2007, pp. 47-64; M. Massari, 'Do All Roads Lead to Brussels? Analysis of the Different Trajectories of Croatia, Serbia-Montenegro and Bosnia-Herzegovina', Cambridge Review of International Affairs, Vol. 18, No. 2, 2005, pp. 259-273.
} 


\section{EU enlargement and the post-communist Balkans}

Approaching its enlargement to the East with a strong rationale for primarily protecting political security and prosperity of its member states, which was in full accordance with the basic motives for its very creation in 1957,2 the EU has strongly contributed to speeding up the post-communist transformation of Central and Eastern European countries and has significantly extended its borders to the eastern part of the European continent. ${ }^{3}$ However, 20 years after the collapse of East European communism, there are remarkable regional disparities regarding the success of post-communist democratisation and economic marketisation that strongly correlate with countries' progress towards EU accession. While the new EU members from Central Europe and the Baltic states are fast catching up with the Western European states in living standards and national urban and rural infrastructures, living conditions in the former communist countries of the Balkan Peninsula and in the non-Baltic successor states of the former Soviet Union are far worse. A partial exception in this regard can be made with Bulgaria and Romania (both of whom joined the EU in 2007) and Croatia (a current candidate for EU membership) which again confirms the existence of a strong correlation between progress in accession into the EU and progress in socio-political and economic reforms (see the indicators given in Table 1).

Although they have received considerably less EU and Western assistance for post-communist reform, the slower progress in developing closer relations with the EU and in post-communist transition in the Balkan states can be hardly explained by a less favourable assessment of the latter by the EU in comparison to Central European or Baltic post-communist states. In contrast to the non-Baltic successor states of the Soviet Union, who have never been seriously considered for developing closer political or economic ties with the European Union - particularly not for getting the opportunity to apply for EU membership 4 - the three largest Balkan states of Bulgaria, Yugoslavia and Romania enjoyed an almost 'equally privileged' status to develop closer and contractual relations with the EU as did the East Central European and Baltic nations in the early 1990s. ${ }^{5}$

Nevertheless, the progress of all the Balkan states in both the intensification of relations with the EU and the accomplishment of the tasks of post-communist

2 J. Zielonka, Europe as Empire: the nature of enlarged European Union, Oxford, New York: Oxford University Press,, 2006 (esp. chapter 2); V. Lintner, The European Community - 1958 to the 1990s' in M-S. Schulze (ed.), Western Europe. Economic and Social Change since 1945, London and New York: Longman, 1999, pp. 140-157.

3 See e. g. H. Grabbe, The EU's transformative power: Europeanization through conditionality in Central and Eastern Europe, Houndmills, Basingstoke and New York: Palgrave Macmillan, 2006; G. Pridham, Designing Democracy. EU Enlargement and Regime Change in Post-Communist Europe, Houndmills, Basingstoke and New York: Palgrave Macmillan, 2005 and M. A. Vachudova, Europe Undivided. Democracy, Leverage, and Integration After Communism, Oxford, New York: Oxford University Press, 2005.

${ }^{4}$ M. Petrovic, 'How far and soon to the East? The prospects for future EU Enlargement', AsiaPacific J ournal of EU Studies, Vol. 2, No. 2, 2004, 121-136.

${ }^{5} \mathrm{M}$. Petrovic, The role of geography and history in determining the slower progress of postcommunist transition in the Balkans', Communist and Post-Communist Studies, Vol. 41, No. 2, 2008, pp. 123-145. 
political and socio-economic reforms has been considerably slower and more difficult than for their Central European and Baltic counterparts. The prime reason for this was mainly related to the effective rejections of EU (and other Western) assistance for reforms by the first post-communist governments in all the Balkan states (including the recent EU newcomers Romania and Bulgaria), which avoided meeting the required criteria for the reception of EU technical and financial assistance. In sharp contrast to all Central European and Baltic post-communist states, these governments were formed of either nominally reformed ex-communist or national-populist parties, which won in the first post-communist elections and were dominated by illiberally oriented members of the ex-communist nomenklatura who simply 'did not need' EU reform assistance because they did not 'want to rush' into reform or into establishing closer conditional relations with the EU. ${ }^{6}$ Once governmental power had been taken by 'real reformers', who were ready to introduce painful economic reforms and meet EU accession requirements, as the Romanian and Bulgarian governments have done since 1996 and 1997, the results came relatively quickly (compare the intensity of the improvement of transition indicators between 1999 and 2006 given in Table 1). However, Albania and the ever-increasing number of the successor states of former Yugoslavia had to wait even longer to begin their 'real' post-communist political and economic transformation. This was accompanied with a new and specially designed EU policy incentive for this group of post-communist states.

This policy incentive was launched only after the 'post-Yugoslav' wars in Croatia and Bosnia and Herzegovina had finally ended and the EU had offered a new and 'coherent strategy' of 'conditionality and [a] gradual approach' in offering EU cooperation and assistance for 'peace and stability, economic renewal, democracy... and [mutual] cooperation' in the 'Western Balkans'.7 The expectation that this new EU strategy, which by 1999 was transformed into the 'Stabilisation and Association Process' (SAP), would boost postcommunist reform and institutionally and socio-politically prepare the Western Balkan states for EU accession was especially strengthened by two positive developments in the year 2000. Firstly, a positive example was set by the successful opening of accession negotiations between the EU and the other two Balkan post-communist late developers - Romania and Bulgaria; secondly, there was an almost simultaneous replacement of the postcommunist authoritarian regimes in the two largest Western Balkan states Croatia and Serbia (then with Montenegro) - by pro-reformist and proEUropean governments in J anuary and October of that year.

\footnotetext{
6 This argument is discussed in more detail in Petrovic, 2008, op. cit. See also S. Fish, The Determinants of Economic Reform in the Post-Communist World', East European Politics and Societies, Vol. 12, No. 1, 1999, pp. 31-78 and M. McFaul, The Fourth Wave of Democracy and Dictatorship. Noncooperative Transitions in the Postcommunist World', World Politics, Vol. 54, No. 2, 2002, pp. 212-244.

${ }^{7}$ EU General Affairs Council, 'Council Conclusions on the Application of Conditionality with a view to developing a Coherent EU-Strategy for the Relations with the Countries in the Region', Annex III, 29/30 April 1997. For more details see C. Pippan, 'The Rocky Road to Europe: The EU's Stabilisation and Association Process for the Western Balkans and the Principle of Conditionality', European Foreign Affairs Review Vol. 9, No. 2, 2004, pp. 219-245 and Petrovic, 2004, op. cit.
} 
Furthermore, after the EU had adopted its 'Thessaloniki Agenda' of J une 2003, which introduced the 'European Partnership for the SAP countries' and clearly concluded that the "ultimate membership [of these countries] into the Union" was a high priority, the 'EU future' of the Western Balkan states seemed secure. ${ }^{8}$ The positive results of these developments were obvious despite some serious internal weaknesses and challenges the then five Western Balkan states had to overcome in the early 2000s. ${ }^{9}$ With only the partial exception of FYR Macedonia 10 in regard to its political stability, all the countries in the region succeeded in significantly accelerating their postcommunist political and economic transformation in a relatively short period of time.

\section{Table 1.}

\section{Political and Economic Transition in post-communist Europe}

\begin{tabular}{|c|c|c|c|c|c|c|}
\hline & \multirow[t]{2}{*}{$\begin{array}{l}\text { Democracy* } \\
1999\end{array}$} & \multicolumn{2}{|c|}{ Democracy* } & \multirow{2}{*}{$\begin{array}{l}\text { Economic } \\
\text { Transition* } \\
1999\end{array}$} & \multicolumn{2}{|c|}{$\begin{array}{l}\text { Economic } \\
\text { Transition* }\end{array}$} \\
\hline & & 2005 & 2008 & & 2005 & 2008 \\
\hline EU-8 (2004)** & 2.12 & 2.03 & 2.13 & 3.4 & 3.7 & 3.7 \\
\hline Romania & 3.54 & 3.39 & 3.36 & 2.8 & 3.2 & 3.4 \\
\hline Bulgaria & 3.58 & 3.18 & 2.86 & 2.8 & 3.4 & 3.6 \\
\hline Croatia & 4.46 & 3.75 & 3.64 & 3.0 & 3.4 & 3.5 \\
\hline Macedonia FYR & 3.83 & 3.89 & 3.86 & 2.7 & 3.0 & 3.2 \\
\hline Albania & 4.75 & 4.04 & 3.82 & 2.6 & 2.9 & 3.0 \\
\hline $\begin{array}{l}\text { Bosnia- } \\
\text { Herzegovina }\end{array}$ & 5.42 & 4.18 & 4.11 & 2.0 & 2.6 & 2.8 \\
\hline Montenegro & 5.50 & 3.79 & 3.79 & 1.6 & 2.6 & 2.8 \\
\hline Serbia & 5.50 & 3.75 & 3.79 & 1.4 & 2.6 & 2.9 \\
\hline Ex-USSR 4*** & 4.92 & 5.46 & 5.48 & 2.3 & 2.6 & 2.8 \\
\hline
\end{tabular}

* Freedom House Nations in Transit 'Democracy score' (1 being the highest; 7 being the lowest) and the simple average of EBRD transition indicators (4+ or 4.3 denotes a standard and performance comparable to advanced industrial economies; 1 denotes little or no change from a "rigid centrally planned economy").

** Average of the five Central European and three Baltic states which acceded to the EU in 2004.

*** Average of Belarus, Moldova, Russia and Ukraine.

Sources: Nations in Transit, Freedom House, New York, various years; Transition Report, European Bank for Reconstruction and Development, London, various years

8 General Affairs and External Relations Council, The Thessaloniki agenda for the Western Balkans: Moving towards European Integration, Council conclusions of $16 \mathrm{~J}$ une 2003, Annex A.

9 The most serious of them were: the armed rebellion of Albanian separatists in Macedonia; the insufficient cooperation of Serbian and Croatian state authorities with the ICTY (International Criminal Tribunal for the Former Yugoslavia) in The Hague; the statehood status of Serbia and Montenegro and Bosnia and Herzegovina and the consequences of the assassination in March 2003 of Zoran Djindjic, the first democratic Serbian Prime Minister since the Second World War (Petrovic, 2004, op. cit.).

10 Former Yugoslav Republic of Macedonia. 
A look at the basic indicators of success in post-communist democratization and economic marketisation (Table 1) illustrates fairly well how the intensification of the EU's presence in the Western Balkans, most notably its conditioned technical and financial assistance for reforms, has produced strong and rapid effects as elsewhere in post-communist Eastern Europe. Apart from FYR Macedonia's stagnation in political democratisation and in apparent contrast to contrary developments in the four European post-Soviet states, which were excluded from the process of EU eastern enlargement and stayed therefore without any significant EU assistance for reform, the Western Balkan states markedly improved their performance in both main streams of post-communist reforms for the period from 1999 to 2005. As a result, they have succeeded in coming closer to both the achieved progress in postcommunist transition of the ex-communist countries of the 2004/2007 EU enlargement and to signing their own pre-accession treaties, i.e. SAAs with the EU. While Croatia and FYR Macedonia had already signed their Stabilisation and Association Agreements with the EU in 2001, the other four joined them with a considerable delay. Albania and Montenegro signed their SAAs during 2007 and Serbia and Bosnia and Herzegovina joined them in May and J une 2008 respectively.

However, the Western Balkan states' individual progress in meeting EU association/accession criteria cannot be considered to be a perfect reflection of their progress in political and economic transition. The cases of FYR Macedonia and Serbia are probably the most indicative and contrasting in this regard. The early signing of the SAA with Macedonia was not a finalisation or reflection of this country's success in post-communist reform, but was rather a stimulus for maintaining an internal ethnic peace negotiated with many difficulties and with the strong involvement of the EU and finalised by the Ohrid Agreement of August 2001. ${ }^{11}$ Serbia, on the other hand, could have signed its SAA at least two to three years earlier regarding most EU conditions and requirements except cooperation with the ICTY in the Hague, which the government of Prime Minister Kostunica was reluctant to completely fulfil in the period 2004-2007 (see part 3 of this text).

While relatively rapid progress during the first half of this decade (especially in comparison to the chaotic and struggling 1990s) strongly confirms the necessity and inevitability of EU support and guidance in conducting successful post-communist reform and thus defines the essence of the Western Balkan states' and people's motives to accede to the EU, it also confirms the rightness of the EU's motivation and policy to expand into this region. The best and almost only guarantee for achieving peace, democracy and economic prosperity in Europe as a whole and in the countries of the Western Balkans as its important part is - as it was with the countries of the

\footnotetext{
${ }^{11}$ See e. g. U. Brunnbauer, The Implementation of the Ohrid Agreement: Ethnic Macedonian Resentments', J ournal on Ethnopolitics and Minority Issues in Europe, 2002(1), pp. 1-23, available at: <www.ecmi.de/jemie/indexauthor.html>; R. Panagiotou, 'FYROM's transition: on the road to Europe?', J ournal of Southern Europe and the Balkans, Vol. 10, No. 1, 2008, pp. 47-64 and B. Vankovska, The Role of the Ohrid Framework Agreement and the Peace Process in Macedonia', in S. Bianchini, J. Marko, C. Nation and M. Uvalic (eds.), Regional Cooperation, Peace Enforcement, and the Role of the Treaties in the Balkans, Ravenna: A. Longo Editore, 2007, pp. 41-63.
} 
2004/ 07 EU enlargement ${ }^{12}$ - the inclusion of these countries in the process of EU accession; hence securing their full compliance with EU membership criteria. However, on the way to EU membership the Western Balkan states still have to overcome some serious challenges, which the previous EU candidates from post-communist Europe either faced to a significantly lower extent or not at all.

\section{The declining support for further enlargement and the increased toughness of EU accession criteria}

After the completion of the 2004 enlargement with the announced accession of Bulgaria and Romania in 2007 and especially following the failed referenda on the EU Constitution in France and the Netherlands in May and J une 2005 and the EU council's decision to open negotiations for accession with Turkey in October of the same year, a significant part of the intellectual and political elite in the 'old' Western members of the Union began to question much more loudly and effectively oppose any further EU enlargement to the east. Fearing that the accession of so many new, economically less developed and sociopolitically 'freshly consolidated' countries - especially Bulgaria and Romania (and possibly Turkey) - may produce seriously negative implications on the future progress and internal stability of the EU and its current member states, they argued that the EU simply cannot 'absorb' any more 'backward' excommunist eastern European countries. Fairly 'westernized' and economically-advanced Croatia is considered to be the 'only possible exception' in this regard. ${ }^{13}$

This stance has started to have effects on Western European and EU political leaders, among who even the leading advocates for further EU enlargement were forced to 'retreat': terms like enlargement fatigue and limited absorption capacity have occupied a lot of attention in enlargement debates. ${ }^{14}$

\footnotetext{
12 Compare Zielonka, op. cit.

13 See e.g. J. Seroka, 'Issues with regional reintegration of the Western Balkans', J ournal of Southern Europe and the Balkans, Vol. 10, No. 1, 2008, pp. 15-29 and W. v. Meurs, 'Rethinking the Balkans. Incongruities of State and Nation Building, Regional Stabilisation and European Integration', Discussion Paper, (Bertelsmann Foundation and Center for Applied Policy Research, Munich, 2004 ), available at:

$<w w w . i s n . e t h z . c h / p u b s /$ ph/ details.cfm?v21=107370\&lng=en\&ord61=alphaNavi\&ord60=Publi cationDate\&id $=46151>$ and the following articles published in the Economist magazine during 2006 and 2007: 'Romania, Bulgaria and the European Union: We're off on a European odyssey. Two poor countries celebrate joining the European Union, but the mood among existing members is glum' (September 28th 2006); 'Enlargement troubles': How did the European Union come to this pass with Turkey - and with enlargement in general? (December 13"th, 2006); 'Bulgaria and Romania: The new kids on the block. The European Union's two newest members, Bulgaria and Romania, are both economically and politically backward' (J anuary 4th 2007); The European Union: The ins and outs. The EU's most effective foreignpolicy instrument has been enlargement. But how far can it go?' (March 15th 2007); 'Postenlargement stress. Support for European Union expansion is under new threat' (November $8^{\text {th }}$ 2007) - all available at:

$<$ www.economist.com/ research/articlesBySubject/ display.cfm?id=682266>.

14 D. Phinnemore, 'Beyond 25-the changing face of EU enlargement: commitment, conditionality and the Constitutional Treaty', J ournal of Southern Europe and the Balkans, Vol. 8, No. 1, 2006, pp. 7-26; M. Emerson, S. Aydin, J . De Clerck-Sachsse, G. Noutcheva, 'J ust
} 
Consequently, despite generally positive and promising development trends among both the new and the old EU members during the first years after the 2004 enlargement (Table 2), 15 the EU has started to discourage further accession by effectively reactivating the importance of the EU's absorption capacity as an accession criterion in spite of its somewhat ambivalent definition. 16

\section{Table 2.}

\section{Average annual real GDP growth, inflation and unemployment rates ${ }^{17}$}

\begin{tabular}{|c|c|c|c|c|c|c|c|c|c|c|c|c|}
\hline & \multicolumn{3}{|c|}{2003} & \multicolumn{3}{|c|}{2005} & \multicolumn{3}{c|}{2006} & \multicolumn{3}{|c|}{2007} \\
\hline & GDP & Inf. & Unm. & GDP & Inf. & Unm. & GDP & Inf. & Unm. & GDP & Inf. & $\begin{array}{c}\text { Unm } \\
.\end{array}$ \\
\hline EU-15 & 1.2 & $2.1^{*}$ & 7.9 & 1.8 & $2.2^{*}$ & 8.1 & 3.0 & $2.2^{*}$ & 7.7 & 2.6 & $2.1^{*}$ & 7.0 \\
\hline Czech & 3.6 & -0.1 & 7.8 & 6.3 & 1.6 & 7.9 & 6.8 & 2.1 & 7.2 & 6.1 & 3.0 & 5.3 \\
\hline Hun & 4.3 & 4.7 & 5.9 & 3.5 & 3.5 & 7.2 & 4.0 & 4.0 & 7.5 & 1.0 & 7.9 & 7.4 \\
\hline Pol. & 3.9 & 0.7 & 19.7 & 3.6 & 2.2 & 17.8 & 6.2 & 1.3 & 13.9 & 6.8 & 2.6 & 9.6 \\
\hline Slvk. & 4.7 & 8.4 & 17.6 & 6.5 & 2.8 & 16.3 & 8.5 & 4.3 & 13.4 & 10.4 & 1.9 & 11.1 \\
\hline Slov. & 2.8 & 5.7 & 6.7 & 4.5 & 2.5 & 6.5 & 5.8 & 2.5 & 6.0 & 6.8 & 3.8 & 4.9 \\
\hline Estonia & 7.6 & 1.4 & 10.0 & 9.4 & 4.1 & 7.9 & 10.0 & 4.4 & 5.9 & 7.2 & 6.7 & 4.7 \\
\hline Latvia & 7.2 & 2.9 & 10.5 & 10.6 & 6.9 & 8.9 & 12.2 & 6.6 & 6.8 & 10.0 & 10.1 & 6.0 \\
\hline Lith. & 10.2 & -1.1 & 12.5 & 7.8 & 2.7 & 8.3 & 7.8 & 3.8 & 5.6 & 9.8 & 5.8 & 4.3 \\
\hline Bulg. & 5.0 & 2.3 & 13.7 & 6.2 & 6.0 & 10.1 & 6.3 & 7.4 & 9.0 & 6.2 & 7.6 & 6.9 \\
\hline Rom. & 5.2 & 15.3 & 7.0 & 4.2 & 9.1 & 7.2 & 8.2 & 6.6 & 7.3 & 6.0 & 4.9 & 6.4 \\
\hline
\end{tabular}

* Euro Area (12 countries, 2003-2006; 13 countries in 2007)

The European Council asked the EU Commission to 'provide a special report on all relevant aspects pertaining to the Union's [Enlargement] absorption

what is this "absorption capacity" of the European Union?', CEPS Policy Brief, No. 113, Centre for European Policy Studies, Brussels, 2006.

${ }^{15}$ Although the indicators shown in the table cover only one year (2007) of the period after the accession of Bulgaria and Romania into the EU, the economic development trends in these two are similarly positive as in the countries of the 2004 enlargement round before and after the accession. Moreover, the economic grouth and speed of reforms in both Bulgaria and Romania accelerated during the first 18 months after their accession (EBRD Transition report 2008, pp. 7), while the negative consequences of the economic crisis of the second half of 2008 and 2009 were much milder in these two than in half of the countries of the 2004 enlargement (i.e. the Baltic states and Hungary - see Eurostat database at

<http:// epp.eurostat.ec.europa.eu/portal/page/ portal/ eurostat/home/ >). The coming years will show whether the much slower progress of both countries in consolidation of the institutions of democracy over the last several years (see their 'democracy scores' in Table 1), especially regarding the elimination of corruption and the strengthening the independence of the judicial system will continue at a similarly slow pace or even worsen as happened in Bulgaria during 2008 (see Nations in Transit, New York: Freedom House, 2009, Country reports on Bulgaria, pp. 143-159). If either of these continues for a longer period of time then the accuracy of the claims of the 'premature' EU accession of Bulgaria and Romania (see e.g. S. A. Andreev, The unbearable lightness of membership: Bulgaria and Romania after the 2007 EU accession', Communist and Post-Communist Studies, Vol. 42, No. 3, 2009, pp. 375-393) and the above noted fears of new EU enlargement(s) founded on these grounds might have been at least partly confirmed.

${ }^{16}$ Although it was included in the original Copenhagen accession criteria, this criterion did not play any significant role in the timing of the 2004 and 2007 enlargement processes.

${ }^{17}$ Eurostat, European Union Statistics, available at: <http:// epp.eurostat.ec.europa.eu>. 
capacity"18 and then, upon the reception of this report, concluded that 'the enlargement strategy based on consolidation, conditionality and communication, combined with the EU's capacity to integrate new members forms the basis for a renewed consensus on enlargement.'19 In fact, this 'renewed consensus on enlargement' was based on the Commission introducing a 'new' more rigorous and tougher 'tool' for negotiating the adoption and implementation of acquis chapters 'on the basis of the lessons drawn from the fifth enlargement' 20 as well as on its obligation to carry out impact studies aiming to establish 'whether the EU can take in new members...without jeopardizing the political and policy objectives established by the Treaties.' 21

Although it was mainly addressed towards potential aspirants from some post-Soviet states and Turkey ${ }^{22}$, with whom negotiations were opened with an 'additional clause' on a limited duration of at least nine years, ${ }^{23}$ this 'new consensus' or 'refreshment' of the conditions for enlargement has also negatively affected the progress and prospects for EU accession of the (Western) Balkan states. Croatia opened the negotiations for accession together with Turkey in October 2005 as an 'open-ended process whose outcome cannot be guaranteed beforehand' 24 and was required to negotiate under 'tougher conditions' of 35 acquis communautaire (instead of 31 as had the 12 countries of the 2004/07 enlargement). The second official EU membership candidate from the region since December 2005, FYR Macedonia, is still waiting to open its accession negotiations with the EU. The EUropean future of the other Western Balkan states, who are currently still in the pre-candidate status, seems to be even less certain despite their expectations to get official candidate status by the end of 2009 or in 2010 at the latest and reaffirmed EU assurances on their eventual membership:

The European Council reaffirms that the future of the Western Balkans lies in the European Union. It reiterates that each country's progress towards the European Union depends on its individual efforts to comply with the Copenhagen criteria and the conditionality of the Stabilisation and

\footnotetext{
18 European Council, Presidency Conclusions, Brussels, 15-16 J une 2006, point.53.

${ }_{19}$ European Council, Presidency Conclusions, Brussels, 14-15 December 2006, point 4.

20 European Commission, 'Enlargement Strategy and Main Challenges 2006-2007. Including annexed special report on the EU's capacity to integrate new members', Communication from the Commission to the European Parliament and the Council, COM (2006) 649 final, Brussels, 8. 11. 2006, p. 6.

21 Ibid, p. 17.

22 It is worth noting that all the Western Balkan states are quite small and as such their accession to the EU cannot be a serious economic burden on the current EU-27. After the exclusion of Croatia, whose accession to the EU is seen as a 'done deal' even by the strongest opponents of further enlargement, the combined population living in all 5 (or 6, if Kosovo is counted as independent) remaining Western Balkan states is some 20 million, which is 2 million less than the current population of Romania or almost four times less than that of Turkey.

23 It has been stated that negotiations with Turkey cannot be concluded before 2014 due to the 'substantial financial consequences' of its potential accession when the new EU budget comes into effect (European Commission, Negotiation Framework [with Turkey], Luxemburg, 3 October, 2005, point 13.

24 Ibid, point. 2 and European Commission, Negotiation Framework [with Croatia], Luxemburg, 3 October, 2005, point, 1.
} 
Association Process. A country's satisfactory track record in implementing its obligations... is an essential element for the EU to consider any membership application, 25

and again, an even more resolute stance:

The European Council reaffirms its full support for the European perspective of the Western Balkans... Recalling its conclusions of December 2006, the European Council stresses that by making solid progress in economic and political reform and by fulfilling the necessary conditions and requirements, the remaining potential candidates in the Western Balkans should achieve candidate status, according to their own merits, with EU membership as the ultimate goal. The EU perspective remains essential for the stability, reconciliation and the future of the Western Balkans. ${ }^{26}$

Nevertheless, with the exception of the most advanced Western Balkan state Croatia, which very likely could have concluded accession negotiations by the end of $2009^{27}$ had they not been blocked by Slovenia from December 2008 to September 2009 due to the two countries' border dispute, the remaining Western Balkan states still have a long way to go to EUrope. The prolonged internal political instability of these states and the consequential inability of their governments to fulfil EU accession criteria appear to be more serious obstacles to their 'assured' EU future than the challenges of the increased toughness of the criteria or the EU's absorption (in)capacity.

\section{Political (in)stability and the statehood status of the potential candidates}

As is more or less regularly repeated in EU Commission and Freedom House annual reports on the state of conditions in the individual countries of the Western Balkan region, the functioning of recently established democratic institutions in these countries is heavily burdened by administrative inefficiency and especially by weak judicial systems which are not able to eliminate the strong influence and involvement of organised crime and corruption in the work of these institutions. The destabilising impact of these political system weaknesses, which are by no means specific to the Western Balkans, ${ }^{28}$ is nonetheless enormously strengthened and prolonged by the continuing existence of internal political dilemmas and conflicts regarding the very statehood status of most of these states.

\footnotetext{
25 European Council, Presidency Conclusions, Brussels, 14-15 December 2006, point 8.

26 European Council, Presidency Conclusions, Brussels, 19-20 J une 2008, point 52.

${ }^{27}$ E. Vucheva, 'Croatia could conclude EU accession talks in 2009', EU Observer, 30. 10. 2008, available at: <http:/ / euobserver.com/9/27019>); P. O' Donnell, 'Rehn: no time for sabbatical', European Voice, Brussels, 26 J une 2008, p.4.

28 They remain a serious obstacle for the further consolidation of democracy in most postcommunist countries of the 2004/2007 EU enlargements, particularly in Romania and Bulgaria (in addition to the above mentioned, see also Reports of the European Commission to the European Parliament and the Council (COM 401 and 402) of $22 \mathrm{~J} \mathrm{uly} \mathrm{2009,} \mathrm{'On} \mathrm{Progress} \mathrm{in}$ Romania [and Bulgaria] under the Co-operation and Verification Mechanism').
} 
With the exception of Albania and partially Croatia, the Western Balkan states remain largely multiethnic societies ${ }^{29}$ with basically problematic and contradictory relations among their major national ethnic groups regarding the political organization of the country they live in, starting from its very constitutional definition. Just emerged from the loose confederation with Serbia, Montenegro - the smallest and most recent UN-recognised Balkan state - remains sharply divided between 'unitarists' and 'separatists' three years after the narrow victory of the pro-independence bloc in the referendum for state independence ${ }^{30}$ and is still waiting for the first electoral change of its post-communist government. ${ }^{31}$ The ethnic peace established between the Slavic majority and Albanian minority in Macedonia by the Ohrid Agreement is fragile and everyday political tensions and problems are clearly reflected in this country's inability to improve its 'democracy score' over the last seven years (Table 1). Furthermore this country's dispute with neighbouring EU member Greece over its official name is still waiting to be resolved, despite numerous attempts and negotiations for finding a compromise solution. ${ }^{32}$ The political tensions in Bosnia and Herzegovina regarding its constitutional status and in Serbia regarding the status of Kosovo may be even more threatening, especially due to their potentially large impacts on the stability of the region as a whole.

The conflicting parties in Bosnia and Herzegovina live now separated into two entities: the Serb Republic of Srpska (Republika Srpska) and the BosniakCroat Federation of Bosnia and Herzegovina (Federacija Bosne i Hercegovine). The Dayton Peace Agreement of November $1995^{33}$ defined Bosnia and Herzegovina as a country with a complicated confederative constitutional order, which could only be effectively implemented with a strong UN civilian and military presence and which has not managed to satisfy any of the national(ist) ambitions of any major ethnic group. ${ }^{34}$ Nevertheless, primarily due to the involvement and pressure of international factors and particularly of the High Representative ${ }^{35}$ and his Office departments, citizens'

29 Following the ratio of $20 \%$ or more of a country's total population used in the above mentioned 'Ohrid Agreement' of 2001 to define the eligibility of ethnic minorities to enjoy a high level of collective and territorial political autonomy, only Albania and Croatia can be defined as mono-national states (with the participation of ethnic minorities of less than 20\%) while all the others including Serbia with Kosovo are multi-national. Croatia in this regard changed its 'status' after the end of its civil war in 1995 (see e.g. P. Eberhardt, (translated by J . Owsinski), Ethnic Groups and Population Changes in Twentieth-century Central-Eastern Europe: history, data, analysis, Armonk, N.Y.: M. E. Sharpe, 2003, esp. pp. 379-385.

30 J. Dzankic, 'Bipolar Worlds of Nation and State in Montenegro', CEU Political Science J ournal, Vol. 2, No. 2, 2007, pp. 192-212; L. McLean, 'Montenegro', Nation in Transit, New York: Freedom House, 2008, pp. 433-453.

31 The Democratic Party of Montenegrin Socialists (formerly the League of Montenegrin Communists) and its president, the current Prime Minister Milo Djukanovic, have been in power throughout the whole period of post-communist development in this country.

32 Due to its potential expansionistic connotation regarding the northern Greek province with the same name, Greece strongly opposes the domestically preferred 'Macedonia'. Therefore the awkward FYR Macedonia is still in use.

33 Formally signed as a peace treaty in Paris on 14 December 1995.

34 R. M. Hayden, 'Democracy" without a Demos? The Bosnian Constitutional Experiment and the International Construction of Nonfunctioning States', East European Politics and Societies, Vol. 19, No. 2, 2005, pp. 567-594.

35 An institution established by the Dayton Agreement and the UN Security Council resolution in order 'to facilitate the Parties' own efforts and to mobilize and, as appropriate, coordinate 
security has been significantly increased, freedom of movement between the invisible ethnic borders has been fully restored and many thousands of former refugees have returned back to their homes in both parts of the state. However, progress in economic reforms and mutual political cooperation between the two entities remains very weak. In managing the necessary economic reforms and post-war recovery the political representatives of all three ethnic groups have continued to rely upon and expect international aid and incentives. ${ }^{36}$ While the leaders of the Bosniak/Croat Federation excuse their poor performance by stating that the 'non-functioning' of federal institutions is due to the Dayton approach being 'too confederative', the Bosnian Serbs' political leaders are preoccupied with defending their 'Dayton autonomy' from such attacks.

Similarly, the post- communist transition of Serbia, its relations with Western countries in general and its progress in the SA process in particular have been almost completely overshadowed by 'capital' national-statehood issues since the assassination of the first post-Milosevic and pro-reformist prime minister Djindjic in March 2003. The two coalition governments formed since this time by Prime Minister Kostunica were much more (pre)occupied with national sovereignty and statehood issues than with the reform and fulfilment of EU pre-accession conditions. Widely seen as a representative of the nationaldemocratic wing in post-Milosevic Serbia, Kostunica was not ready to completely break away from the legacy of Milosevic's regime and did not hesitate to worsen and even sever relations with the West and the EU when he found it necessary for protecting national 'dignity'. ${ }^{37}$ In this manner, he completely stopped any extradition of war crime accused to the ICTY in The Hague after he took power in 2004. While reform of the Serbian economy, was seriously slowing down (primarily due to low foreign investment inflows) and the opening of the negotiations for signing the Stabilisation and Association Agreement with the EU perpetually postponed, Kostunica openly declared that he preferred voluntary surrender rather than the arrest of those indicted by the Hague Tribunal. 38

Once the Kostunica government finally succeeded in persuading some of the accused to surrender to the ICTY in 2005, for which the EU awarded Serbia by opening negotiations for the SAA in October 2005, two other national interest issues directly related to the country's statehood quickly pushed (again) the question of progress in post-communist reform and EU accession from the

the activities of the organizations and agencies involved in the civilian aspects of the peace...'

(Dayton Peace Agreement, Annex 10, Article I, available at:

$<w w w . s t a t e . g o v /$ www/ regions/ eur/ bosnia/ bosagree.html>).

36 Hayden, op. cit.; G. Knaus and M. Cox, Bosnia and Herzegovina: Europeanisation by decree' in J . Batt (ed.), The Western Balkans: moving on, Chaillot Paper, No. 70, Paris: Institute for Security Studies, 2004, pp. 55-68.

${ }^{37}$ R. F. Miller, 'Dealing With the Communist Past: The Special Case of Yugoslavia', The South Slav J ournal, Vol. 23, 2002, pp. 3-27. See also J. N. Clark, Vojislav Kostunica - some reflections on his time as Serbian Prime Minister', Journal of Southern Europe and the Balkans, Vol. 10, No. 1, 2008, pp. 31-46.

38 See e.g. D. Konjukusic, 'Kostunica Continues to Delay Cooperation With the Hague', Southeast European Times, 30 December 2004, available at:

$<w w w . s e t i m e s . c o m /$ cocoon/ setimes/ xhtml/ en_GB/ features/ setimes/features/2004/ 12/30/fe ature-02>. 
priority list of the Serbian government's agenda. The first of these two, the long announced separation of Montenegro, was relatively smoothly accepted even by the Kostunica government and the national political elite as a regrettable inevitability despite the very narrow results of the referendum and 210 complaints from the Montenegrin unionist opposition about its regularity (which all were quickly rejected by the EU appointed chairman of the Referendum commission). ${ }^{39}$ However, the second issue, the solution of the socalled 'Kosovo status', is still strongly shaking the Serbian political scene.

While it is clear that any political instability in a country which seeks closer cooperation or integration with the EU will directly and negatively affect this country's capacity to successfully fulfil EU conditions for cooperation/ integration, the reverse - the impact of the increased toughness of EU accession criteria on the prolonged political instability of a country in question - is less obvious and direct. Although definitely not helpful, the emergence of enlargement fatigue and the increased toughness of the accession criteria can hardly be considered as directly linked to the prolonged (non)resolution of the 'open' statehood disputes in the Western Balkans which remain, as shown above, the main cause of the prolonged internal political instability in the Western Balkan states. In addition to the above discussed contrasting positions of the disputed national and ethnic groups, where it is extremely difficult to find a mutually satisfactory solution, some more direct policy incentives and actions introduced by the EU and its member states towards finding resolutions to 'open' statehood questions in the Western Balkans have been much more important in this regard. ${ }^{40}$ The following section provides a closer look at these incentives.

\section{The necessity and sensitivity of the EU's nation-building role in the Balkans}

Since the collapse of the Yugoslav common state in the early 1990s political and intellectual elites of national and ethnic groups which had lived together for over 70 years have shown a remarkably high level of reluctance to find mutually acceptable solutions to their different views on national and statehood issues. While it can be argued that neither the dissolution of postcommunist Yugoslavia nor its accompaniment with the outbreak of ethnic wars in Croatia and Bosnia-Herzegovina were exclusively 'Balkan specifics', 41

39 For more details see K. Friis, The Referendum in Montenegro: The EU's 'Postmodern Diplomacy', European Foreign Affairs Review, Vol. 12, No. 1, 2007, pp. 67-88.

40 It can be argued that the shortcomings of some of these incentives, especially those introduced in the most recent years, could have been related to their inadequate preparation and formulation, which had resulted from a lack of a real interest by the major Western members of the EU for (EU enlargement into) the Western Balkans. Such an argumentation however needs to be confirmed by a more thorough investigation, which is beyond the scope of this paper.

41 The other two multinational communist states in Europe - Czechoslovakia and the Soviet Union - also collapsed soon after the overthrow of communist party rule. In many regions of the latter ethnic violence and conflicts became a frequent phenomenon (See e.g. V. Bunce, Subversive institutions: the design and the destruction of socialism and the state, Cambridge, UK, New York: Cambridge University Press, 1999; S. R. Bollerup and C. D. Christensen, Nationalism in Eastern Europe. Causes and Consequences of the National Revivals and 
the intensity of conflict regarding the level of violence and destruction were incomparably higher in the two post-Yugoslav states than anywhere else in post-communist Europe. Consequently, the process of post-war reconstruction in these countries has been more difficult and demanded more time as reconciliation has been complicated and painful. International assistance has been as necessary in this regard as it has been for the successful post communist political and economic transition of these and other East European countries.

The presence and attempts of the EU and the so-called international community' (most importantly the USA, UN, OSCE and some NGOs) to help conflicting ex-compatriots find a mutually acceptable solution were extensive but also ambiguous and confusing at the beginning of Yugoslavia's postcommunist history. In less than a year it had reached full circle: from strong support for the single Yugoslav state and its inclusion into the Western European integration at the beginning of 1991 to the recognition of Slovenian and Croatian independence and the de-facto recommendation of the so-called 'Badinter Committee'42 to the other Yugoslav constituent republics to do the same by the end of that year. ${ }^{43}$ If it had seemed that EU policy towards the countries of the Western Balkans was becoming more coherent and effective with the launching of a 'coherent strategy' and SAP in the late 1990s, more recent EU political incentives relating to solving the statehood status of individual states in the region did not appear to be particularly coherent or productive.

If the EU-supervised Ohrid agreement was necessarily 'unique' in granting a very large level of territorial and functional autonomy to the Albanian national minority, which did not completely satisfy either of the involved parties and particularly not the Slavic majority, ${ }^{44}$ the need for a different EU approach towards the redefinition of the constitutional status of the other multinational states in the region is far less clear. This becomes especially apparent when considering the fact that it can negatively impact the fragile political stability of FYR Macedonia established by the above agreement.

Conflicts in Late-Twentieth-Century Eastern Europe, London and New York: Macmillan Press Ltd, St. Martin's Press INC, 1997 and Petrovic, 2008, op. cit.).

42 The Arbitration Committee of the Conference on Yugoslavia founded by the Council of Ministers of the European Community on 27 August 1991.

${ }^{43}$ For more details see L Cohen, Broken Bonds. Yugoslavia's Disintegration and Balkan Politics in Transition, 2nd edn. Boulder, Colo.: Westview Press, 1995; J. Eyal, Europe and Yugoslavia: Lessons from a Failure, London: Royal United Services Institute for Defence Studies, 1993; S. L. Woodward, Balkan Tragedy. Chaos and Dissolution after the Cold War, Washington D.C.: The Brookings Institution, 1995 and M. Petrovic, The European Union and the Difficult Transition in South-Eastern Europe' in I. Lilly and K. Bosselman (eds.), Repositioning Europe, Perspectives from New Zealand, Christchurch: National Centre for Research on Europe, University of Canterbury, 2003, pp. 111-133.

44 See Brunnbauer, op. cit and Vankovska, op. cit. 
In the case of the former 'state union' 45 of Serbia and Montenegro the EU again went through a full circle: from assistance in signing the agreement which kept these two constituent republics of the former Yugoslavia together to assisting and supervising the Montenegrin referendum for independence just four years later. On the other hand, the EU has strongly and persistently supported strengthening the central government institutions in Bosnia and Herzegovina over the last several years. In November 2003 the EU Commission's Feasibility Study reviewed B-H's readiness to open negotiations on signing a SAA and identified 16 'reform areas' which should be successfully addressed prior to the opening of the negotiations. These mostly related to the strengthening of administrative, economic and political power of central government institutions while the more recent EU requirements define the necessity of the country's constitutional change in the same direction as the sine qua none for its progress in the SAP and towards EU accession. ${ }^{46}$ Curiously, the EU did not express any similar ambition to persuade related parties (especially the Montenegrin government) to strengthen the role of the central institutions of Serbia and Montenegro despite relatively strong support for this in Serbia and mixed attitudes (definitely not the consensual opposition as shown above) in Montenegro.

According to Maurizio Massari, 47 the ambiguity of the EU's and 'international community's' approach towards the solution of the statehood status of these two multi-ethnic states has

...often paradoxically exacerbated Serbia-Montenegro's and BiH's problems... the EU's insistence on postponing, via the union, the definition of Montenegro's status has eventually backfired, reducing the chances of both Serbia and Montenegro to start the SAA process. The EU could have earlier avoided forcing Montenegro into the Belgrade agreement or, once the union was established, it could have acted to guarantee that Montenegro respects the terms of the agreements. But it did neither of these two...48

Moreover, by deciding to introduce the so-called 'twin track' policy for the separate negotiations of a SAA feasibility study with the two constituencies of the state-union in September 2004, the EU effectively gave up on the state whose constitutive order was created under its direct guidance only two years earlier. ${ }^{49}$ While this inconsistency in the EU's approach towards the solution

45 According to the definition of the common state given in the agreement signed under the presence and supervision of the European Union High Representative for CFSP J avier Solana on 14 March 2002; subsequently adopted by the parliaments of both republics and the federal parliament on 4 February 2003 as The Constitutional Charter of the State Community of Serbia and Montenegro'.

46 See European Commission, Bosnia and Herzegovina 2007 [and 2008] Progress Report, SEC (2007)1430, Brussels, 6. 11. 2007 [and SEC(2008)2693final, 5.11. 2008] and EU Council, 'Council Decision of 18 February 2008 on the principles, priorities and conditions contained in the European Partnership with Bosnia and Herzegovina and repealing Decision 2006/55/ EC', (2008/211/ EC), Brussels, 2008.

47 A high ranking Italian diplomat and the Head of the OSCE Mission to Serbia and Montenegro from 2002 to 2006.

48 M. Massari, op. cit., pp. 259-273.

49 Therefore, the argument that the EU has negatively impacted the SAP and the accession potential of the 'weak and unsustainable states' of Serbia and Montenegro and Bosnia and Herzegovina by supporting their existence (N. Tzifakis, op. cit; Meurs, op. cit.) can be only 
of the statehood status of Serbia-Montenegro and Bosnia-Herzegovina could have been partly explained by the 'confusion' over the existing differences between these two confederations regarding the implementation of the principles of the exclusive right of the federal units to secede from the excommunist federations and the non-alteration of their internal borders, 50 the recent incentives regarding the recognition of Kosovo's independence by the leading members of the EU and some other countries, particularly the USA can hardly fit in with any previously adopted international rule or practice.

The leading proponents of such a solution, the Western members of the socalled 'Contact group'51 as well as some NGOs, ${ }^{52}$ have therefore decided to legally treat it as a sui generis case that cannot be used as a precedent for other breakaway regions in the world. 53 This formulation was also adopted by the European Council, 54 but was still not considered as a convincing enough assurance by all EU member states or by the vast majority of countries in the world for them to be motivated to recognise this independence. One and a half years after its unilateral declaration on 17 February 2008, Kosovo's independence has been recognised by 62 out of 192 member states of the UN. ${ }^{55}$ Among those who have recognised it are the USA, Canada, Australia, Japan and 22 EU member states, while the remaining five EU members Spain, Slovakia, Romania, Cyprus and Greece - have declared that they will not recognise Kosovo's independence without Serbia's consent as have two permanent members of the UN Security Council - Russia and China. On the

partially correct and used as an interpretation of EU policy towards the former state-union for a very limited period of time (of some two and one half of years).

50 Introduced by the Badinter committee's decisions regarding the dissolution of former Yugoslavia and later followed in the dissolution of the Soviet Union and Czechoslovakia (See e.g. P. G. Roeder, The Triumph of Nation-States: lessons from the Collapse of the Soviet Union, Yugoslavia and Czechoslovakia' in M. McFaul, K. Stoner-Weiss (eds.), After the Collapse of Communism. Comparative Lessons of transition, Cambridge: Cambridge University Press, 2004), pp. 21-57; and P. Radan, 'Post-Secession International Borders: A Critical Analysis of the Opinions of the Badinter Arbitration Commission', Melbourne University Law Review, Vol. 24, No. 1, 2000, pp. 50- 76.

${ }^{51}$ An informal grouping of influential countries interested in Balkan affairs formed during the Bosnian civil war. It is comprised of the United States, the United Kingdom, France, Germany, Italy and Russia.

52 The International Crisis Group has been especially active in promoting Kosovo's independence as the 'only and urgent solution'. See its report Kosovo: Toward Final Status' of 24 January 2005 and its following reports on Kosovo, (available at: <www.crisisgroup.org/home/ index.cfm?id=1243\&l=1>), which presents the rationale and proposes the necessary steps towards Kosovo's independence with or without Serbia's consent. This was later fully adopted by the US and Western European members of the Contact group as non-negotiable terms for the solution of 'Kosovo's status'. Serbia's later proposals on 'substantial autonomy' upon the basis of a 'Hong-Kong model' or the Finnish/ Swedish Oland Islands' status' as well as any 'third' proposals have never been seriously considered. See Serbian Government, Brussels, November 20, 2007: 'Oland Islands example of successfully functioning autonomy in Europe', available at: $<w w w . s r b i j a . g o v . r s / v e s t i / v e s t . p h p ? i d=40944 \& q=K o s o v o+s t a t u s>$; and M. Emerson, 'Kosovo merits "special status as part of the EU”', CEPS Policy brief, No. 143, October 2007, available at: <http:// shop.ceps.eu/ BookDetail.php?item id=1547>.

53 For more details on this argument see Selver B. Sahin, The use of the 'exceptionalism' argument in Kosovo: an analysis of the rationalization of external interference in the conflict', J ournal of Balkan and Near Eastern Studies, Vol. 11, No. 3, 2009, pp. 235-255.

54 European Council, Presidency Conclusions, Brussels, 14 December 2007, point 69.

$55<$ http:// www.kosovothanksyou.com/ >. 
other hand, Russia has already set a 'precedent' and recognised the independence of the rebellious Georgian provinces of South Ossetia and Abkhazia.

The first outcomes of the proclamation of Kosovo's independence and its partial recognition correspond more to gloomy scenarios expressed by the opponents of such an action ${ }^{56}$ than to optimistic 'promises' that Kosovo's independence will significantly improve regional stability. Ethnic Albanians and Serbs in Kosovo live strictly divided and monitored by international troops as they used to before the proclamation of independence. The major difference in this regard is in the confusion over who holds authority for the international civilian presence (the military presence is clearly secured by the 17,000 strong NATO-led forces: KFOR): whether it should be under the new EU appointed mission EULEX, which according to the original Ahtisaari's plan 57 should help building new government institutions of independent Kosovo or whether it should stay within the UN (i.e. UN Security Council's) mission UNMIK as insisted by Kosovo Serbs and Serbia. ${ }^{8}$ Such political circumstances can be hardly evaluated as more beneficial for the development of Kosovo's extremely weak economy than those of the 'pre-status period' when '[t]he uncertainty over the future political status of Kosovo affect(s) every area of economic policy.'59 Furthermore, until the five remaining EU member states decide to recognize Kosovo independence - and there are no signs that will happen anytime soon, especially since the UN Assembly decision of 8 October 2008 to accept Serbia's incentive to seek an opinion from the International Court of Justice on legality of Kosovo's independence'60 - Kosovo cannot establish formal legal relations with the EU or launch a feasibility study for a future Stabilisation and Association Agreement.

On the other hand, Western support for Kosovo's independence was the second largest challenge to the post-communist democratisation of Serbia after the assassination of Prime Minister Djindjic. While the nationalist opposition and Kostunica's national-democratic bloc in the governing coalition 'just waited' for something like this as casus belli for demanding the

\footnotetext{
56 Among these were some highly-ranked diplomats and experts from countries which were the main supporters of the unilateral declaration of Kosovo independence. Note the comments of J ohn Bolton, the former permanent U. S. representative to the UN, and Lawrence Eagleburger, the former U. S. Secretary of State: 'Warning Light on Kosovo', The Washington Times, January 31, 2008 as well as the article by J onathan Eyal, Director of International Security Studies at the Royal United Service Institute, London: 'Kosovo's Independence. Re-Writing the Balkans, the Wrong Way Around', RUSI J ournal, Vol. 153, No. 1, 2008, pp. 22-29.

${ }^{57} \mathrm{~A}$ formal plan for the introduction of gradual, 'internationally monitored' independence for Kosovo presented by UN Special Envoy Martti Ahtisaari, former president of Finland and the 2008 Nobel Peace Prize winner in early 2007, which was immediately rejected by Serbia as a violation of its territorial integrity and UN resolution No. 1244 (of $10 \mathrm{~J}$ une 1999) which confirmed this integrity and authorized the UN interim administration in Kosovo.

58 See e.g. E. Vucheva, 'Kosovo Serbs protest against EU mission', EU Observer, 3.10.2008, available at: <http://euobserver.com/15/26858>; and E. Vucheva, 'One year after independence, Kosovo needs 'a revolution', EU Observer, 17.02.2009, available at: $<\mathrm{http}$ // euobserver.com/ ?aid=27621>.

59 European Commission, Kosovo Under UNSCR 12442007 Progress Report', SEC(2007) 1433, Brussels, 6.11.2007, p. 24.

60 United Nations, General Assembly, GA/10764, New York, 8 October 2008.
} 
cancellation of any country's ties with 'Serbia's enemies in the West', the two 'pro-western' parties in the governing coalition continued to insist on the motto of 'Serbia in the EU, with Kosovo' despite very little 'empirical evidence' for such a claim. Nevertheless, Tadic, the post-Djindjic leader of the Democratic Party and President, who himself barely defeated his ultranationalist opponent in the presidential elections in February 2008 with a majority of only some 100,000 votes, succeeded in forming a pro-reformist and pro-European government with Milosevic's former Socialist Party while permanently repeating that 'Serbia will never recognise Kosovo's independence'.61

How long this stance can keep going on 'separately together' with Serbia's European ambitions and progress in SAP is difficult to predict, especially in light of the importance and objective need for close and intensive regional cooperation and Serbia's key role' in it:

Serbia has a key role to play in the region from an economic and political point of view. Serbia is also important for the stability of the region. . Regional cooperation and good neighbourly relations are more important than ever for enabling Serbia and the region as a whole to continue moving towards the EU.62

However, throughout 2008 Serbia's political relations with its Western Balkan neighbours have dropped to the lowest level ever since Milosevic's overthrow. Traditionally good relations with FYR Macedonia and relatively correct relations with the Montenegrin government have been effectively frozen since these two countries recognised the independence of Kosovo in a coordinated action on 9 October 2008, a day after the UN Assembly decision to ask the International Court of J ustice for an opinion on Kosovo's independence was adopted. Significantly improved relations between Serbia and Croatia in recent years have also become less cordial since Croatia was one of the first countries to recognise Kosovo, while complex relations with the Bosniaks' (Bosnian-Muslim) political representatives have further deteriorated due to the Bosniaks' worsening relations with Bosnian Serbs and an insistence of the fundamental change to the country's Dayton constitution regarding the autonomy of the Republic of Srpska. The increased internal instability of Bosnia-Herzegovina, which remains the only country in the region apart from Serbia yet to recognise Kosovo independence, can also be seen as a reflection of the EU/international recognition of Kosovo's independence. ${ }^{63}$

Although other elements of inconsistency in the EU's SAP and accession policy towards the Western Balkan states can be identified, 64 the inconsistency of the EU's approach towards the solution of the statehood status of the multi-

\footnotetext{
${ }^{61}$ For more details on Tadic's position on Kosovo and Serbia's desire to accede to the EU see B. Tadic, 'Resolving the Kosovo Crisis', Hampton Roads International Security Quarterly, Portsmouth, April 15, 2008, pp. 30-32.

62European Commission, 'Western Balkans: Enhancing the European perspective', Communication from the Commission to the European Parliament and the Council, COM (2008) 127 final, Brussels, 5.3.2008, p. 6.

63 See Eyal, op. cit., and E. Vucheva,' EU sounds alarm on Bosnia's stability', EU Observer, 23.10.2008, available at: <http:// euobserver.com/9/26982>.

64 E. T. Fakiolas and N. Tzifakis, op. cit., pp. 377-398; Massari, op. cit.
} 
national/multi-ethnic states is the most serious deficit in the recent EU's policy incentives towards the Balkan region. The 'incomplete recognition' of the independence of Kosovo by $22 \mathrm{EU}$ members without a reached consensus within the EU and the compromise with the pro-democratic and proEuropean political majority in Serbia is particularly problematic due to its potentially large negative impacts on the ability of both Serbia and Kosovo to continue with reform and a pro-European path and political-ethnic stability in the neighbouring multi-national states, especially Bosnia-Herzegovina and Macedonia. Even under the optimistic assumptions that further destabilisation of the neighbouring multi-national states will be avoided with strong involvement and pressure by the EU and that Serbia will for its own sake gradually improve damaged relations with its neighbours, there are at least three problems brought to the region by the partial recognition of Kosovo's independence that will stay unresolved so long as the current status quo continues:

1) Serbia-Kosovo political relations stay frozen while trade, economic, cultural, transit and all other relations between these two parties become more complicated and deteriorate to a significantly lower level than would have been the case had a mutually acceptable solution been found;

2) Kosovo cannot become a 'normal' independent state which is recognised by the UN and which is able to apply for membership in many other international organisations including the EU;

3) The process of accession into the EU of both Kosovo for formal reasons (it is not recognised by all EU member states) and Serbia for political reasons (it does not want to 'cooperate' with the majority of 22 EU members and recognise Kosovo's independence) are effectively suspended.

The longer the current status quo continues or the dark 'Balkan ghetto'65 scenario is activated, the more instable and unsecured will be all the countries in the region, while their EU future will remain only a 'potential' one.

\section{Conclusion}

While successfully supporting and promoting post-communist reform and preparation for EU membership in the countries of Central Europe and the Baltics, EU enlargement leverage did not have any particular effects on postcommunist developments in the Balkan region during the 1990s. Only after pro-reformist governments strongly committed to accession into the EU had finally been elected to power and after the EU had simultaneously adopted a 'coherent strategy' and Stabilisation and Association Process for the Western Balkans did enlargement leverage start to produce positive impacts in this part of post-communist Europe. However, while significantly contributing to the speeding-up of economic reforms and the initial consolidation of democratic institutions in all of the countries in the region, the 'coherent strategy' and SAP conditional approach have not been able to completely eliminate political instability in the multi-national states in the region. This

65 Massari, op. cit, p. 271. 
remains a major obstacle to the integration of these states and the region as a whole into the Union.

The second major obstacle for the faster accession of Western Balkan states into the EU is of an entirely external nature and is related to the increased 'enlargement fatigue' in the core Western members of the EU since 2005 (and especially since 2007) which appears to be making tougher conditions for accession for the new entrants despite the constantly repeated promises of the 'secured EU future' for all the countries in this region. Furthermore, the inclusion of the clause of the EU's 'absorption capacity' as a part of this tougher package actually considers the possibility of the rejection of a membership application even in the event when a candidate successfully fulfils all the other required criteria (i.e. the 35 acquis communautaire chapters).

While the absorption capacity criterion is tough, especially because it is out of the sphere of influence of the potential accession candidates, its relevance for the EU membership aspirations of the small Western Balkan states has always been quite limited. After the Irish 'yes' to the Lisbon treaty in October 2009, this criterion has become effectively irrelevant even for Croatia, the only country in the region whose soon expected accession could have been affected by the implementation of the EU's absorption incapacity to accept any new members while waiting to adopt its new institutional arrangements. On the other hand, the prolonged internal political instability of the multi-national Balkan states, 'assisted' by the EU's omission to provide more viable proposals for defining the statehood status of these states appears to be a more serious hurdle, which may postpone the inclusion of most Western Balkan states into the European Union for a longer period. Furthermore, if not solved in the reasonably near future, it can become again a focal point for the destabilisation of the Balkan region as a whole with considerable negative economic and socio-political implications on many neighbouring EU member states. 